\title{
High Gain DC/DC Converter with IC MPPT Algorithm For DC Micro-Grid Applications
}

\author{
Subbarao Mopidevi ${ }^{1}$, Thanikonda yedukondalu ${ }^{2}$, Polamraju.V.S.Sobhan ${ }^{3}$ \\ ${ }^{1}$ Associate Professor,Department of Electrical and Electronics Engineering, Vignan's Foundation for Science, \\ Technology and Research, Vadlamudi, Andhra Pradesh \\ ${ }^{2}$ Assistant ProfessorDepartment of Electrical and Electronics Engineering,KLR college of \\ engineering \& technology \\ ${ }^{3}$ Associate Professor,Department of Electrical and Electronics Engineering, Vignan's Foundation for Science, \\ Technology and Research, Vadlamudi, Andhra Pradesh \\ subbarao.mopidevi@gmail.com,tkondalu@gmail.com,pvssobhan@gmail.com
}

\begin{abstract}
High gain DC-DC converter with IC MPPT algorithm, solar \& wind as inputs in conjunction with this converter are presented in this paper. Recently, due to increase in the green energy demand the renewable energy resources are widely used.DC micro grids are now of significant importance due to the rise in DC loads and the demand for high power quality. These DC loads require various levels of voltage based on their power ratings. The proposed step-up DC-DC converter therefore has a high voltage gain with optimum duty ratio characteristics. In addition, the additional benefit of delivering electricity at two distinct voltage levels is that it is more suitable for DC micro grid applications and all the switches are controlled using single control signal which reduces complexity. The proposed converter is implemented and theoretically verified in SIMULINK MATLAB software for two different load power ratings of $100 \mathrm{~W}$ and $200 \mathrm{~W}$.
\end{abstract}

Keywords-DC-DC Converter, Voltage gain, Microgrid, Duty cycle, Maximum Power Point Tracking (MPPT)

\section{Introduction}

In recent years, due to severity of global energy crisis and environmental issues there has been a rapid rise in concern about green energy[1,2]. This results in the discovery of the use of renewable energy sources to produce DC electricity, such as solar energy, fuel cells, etc. DC Micro-Grids offer a natural alternative for green energy incorporation. The other significant factor is that most market loads, such as TVs, LED lamps, ceiling fans, computers, etc., are based on DC or adaptable to DC, requiring various voltage levels based on their power ratings[3,4]. Solar energy is one of major renewable energy source because of their merits like absence of fuel cost, no noise and little maintenance etc. The output from PV resource is essentially a low signal voltage due to this drawback there is a need for boost converter [5]. As an interface between the load and the source. The traditional boost converter, such as cascaded boost converter, switched capacitor converter, etc., provides high gain at extreme duty ratios resulting in significant power switch voltage tension, reverse recovery issues, electromagnetic interference, etc. DC-DC Converter is used to solve those problems with high gain step up [6,7]. Fig. 1 shows the block diagram of DC Micro-Grid 


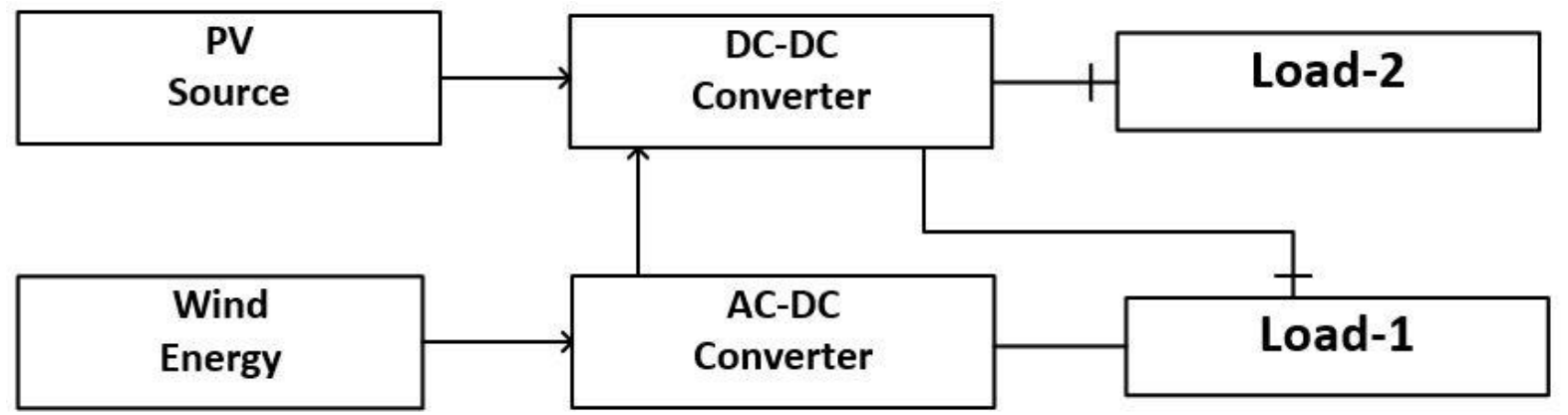

Fig. 1.Block Diagram of DC Micro-Grid

Because of the non-linear characteristics of PV array the maximum power can be extracted under particular voltage conditions. In this regard MPPT techniques are used in PV generating system to maximize the output power. Therefore, the dynamics of PV array is simulated various solar irradiance and cell temperature. So as to control the output voltage, the IC MPPT technique is used. In this paper a High efficiency high voltage gain step up DC-DC converter with IC MPPT method and conjunction of solar and wind energy is proposed to serve as inputs.

\section{Configuration of circuit of proposed converter}

The Converter is capable of maintaining two different Voltage levels. This Converter uses two high voltage Capacitors namely $\mathrm{C}_{1}$ and $\mathrm{C}_{2}$,two Inductors $\mathrm{L}_{1}$ and $\mathrm{L}_{2}$, three Diodes represented as $D_{1}, D_{2}$ and $D_{3}$ and also controlled power Switches $\mathrm{S}_{1}, \mathrm{~S}_{2}, \mathrm{~S}_{3}$ which are taken as high frequency MOSFETs to maintain two Voltage levels and $V_{s}$ is the low voltage PV source as shown in Fig.2(a) .Based on the duty cycle the controlled switches are operated at two different voltage levels. As this converter requires only one control signal to operate all the controlled power switches. This circuit operates in two modes that is when all switches are turned off and in mode 2 all the switches are turned on which are shown in the Fig. 2(b) and 2(c).Specifications of the system is shown in table 1.

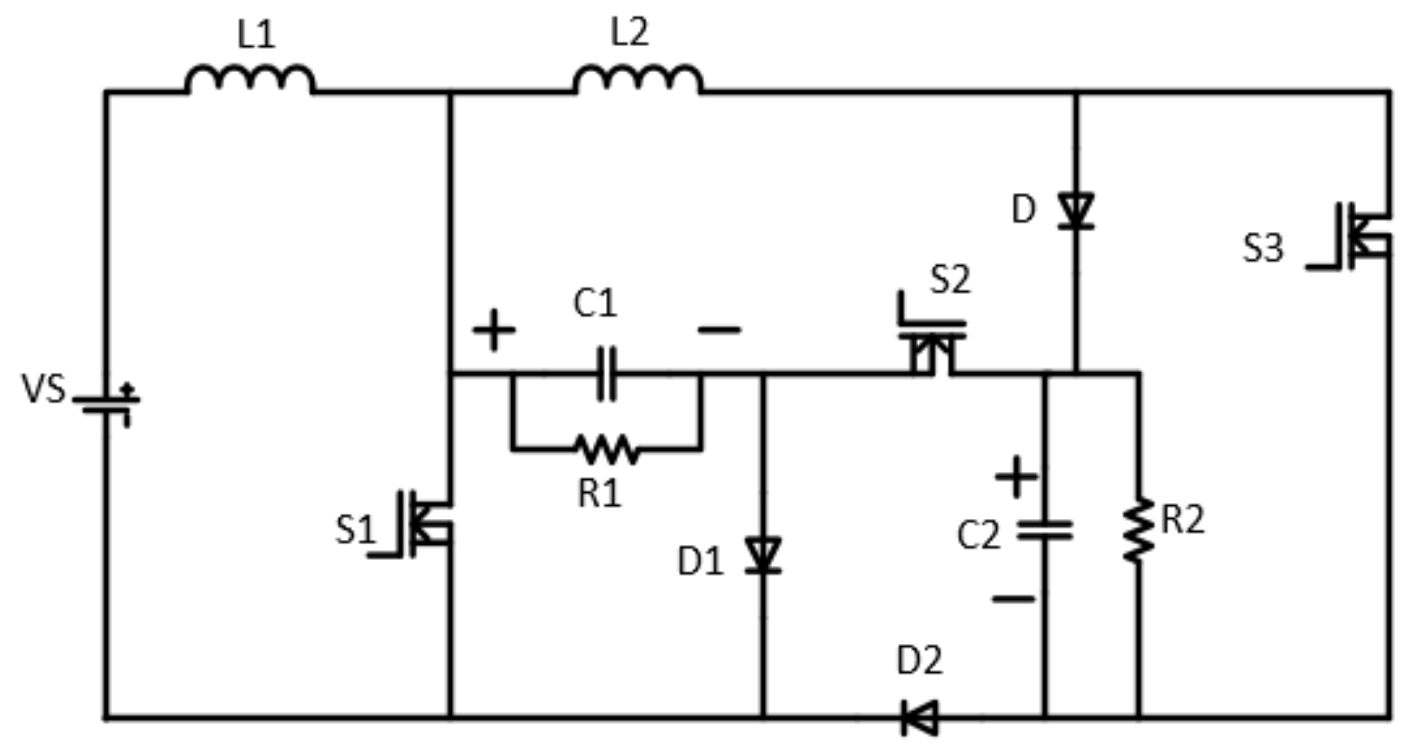

Fig. 2(a). Circuit diagram of DC-DC Converter with load 


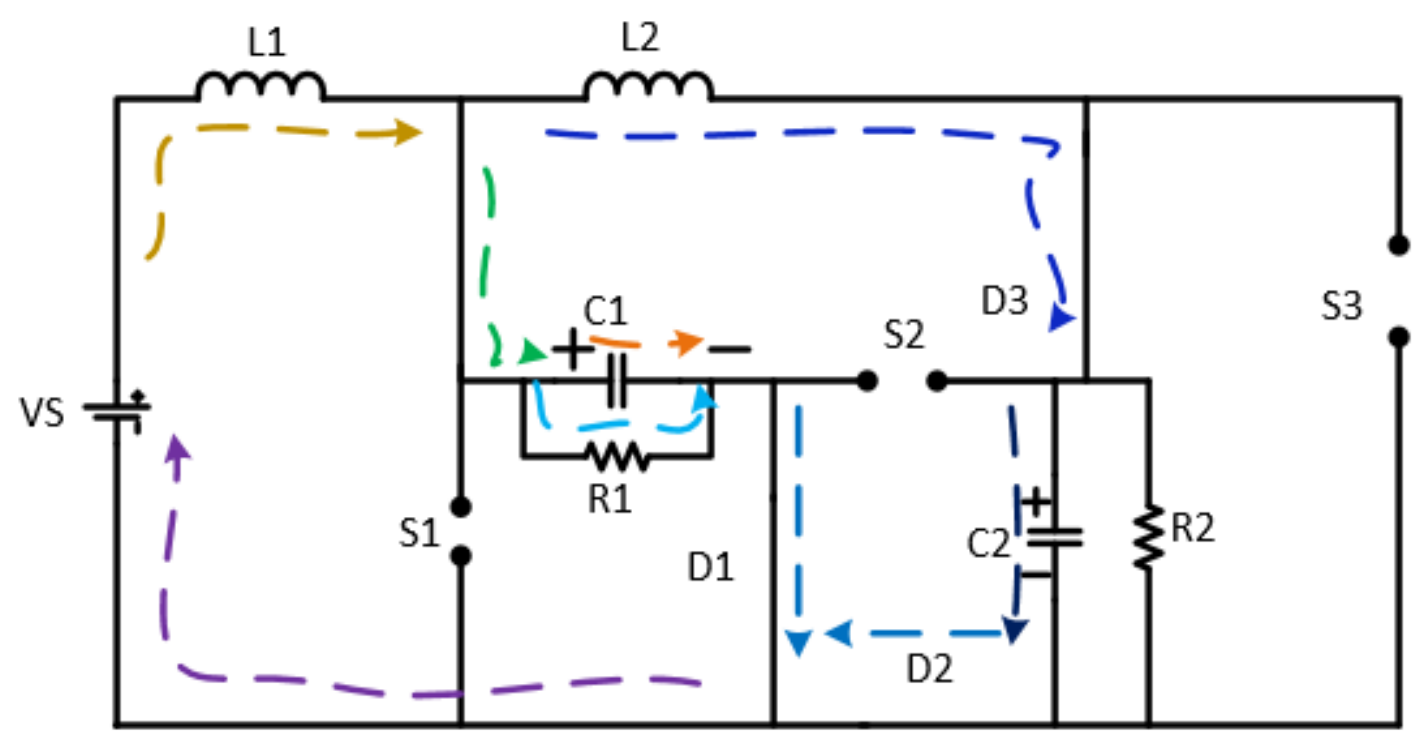

Fig. 2(b). Controlled switches $\left(S_{1}, S_{2} \& S_{3}\right)$ are OFF

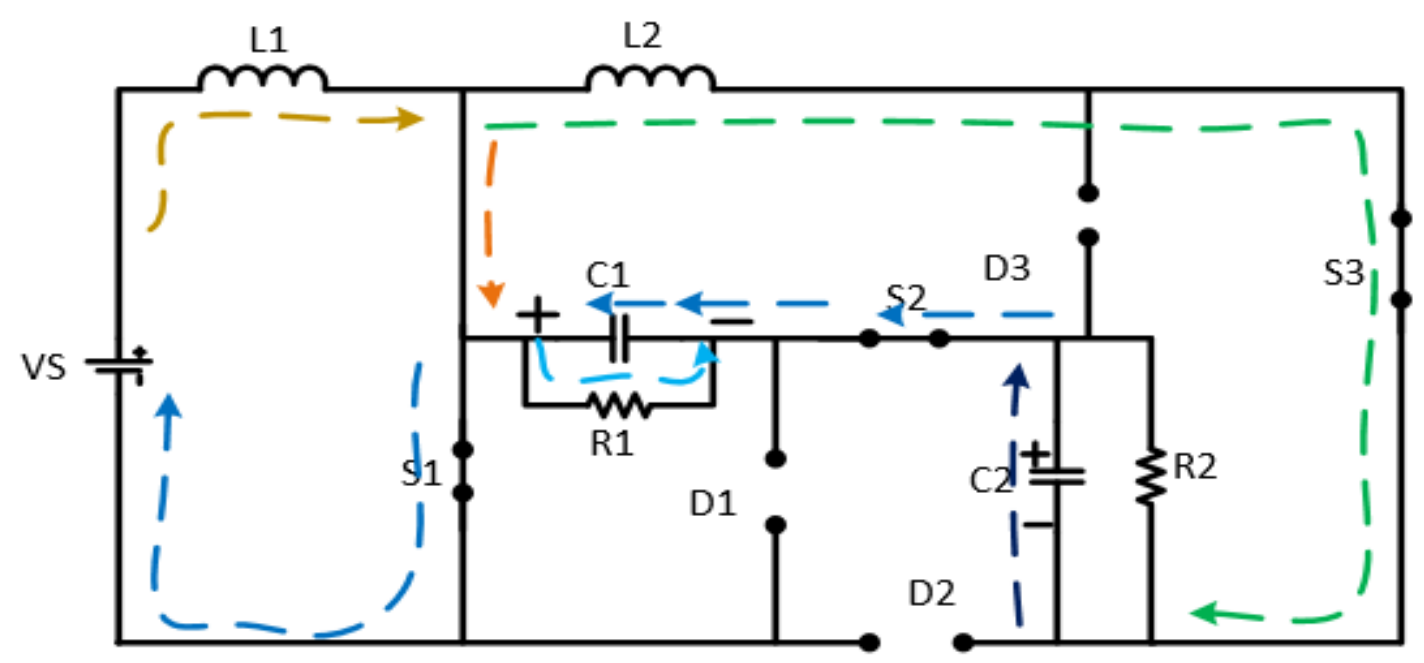

Fig. 2(C) .Controlled switches $\left(S_{1}, S_{2} \& S_{3}\right)$ are ON

Table 1. Specifications

\begin{tabular}{|c|c|}
\hline Designing Specifications & Values \\
\hline Switching frequency & $10 \mathrm{KHZ}$ \\
\hline Source voltage & $48 \mathrm{~V}$ \\
\hline Power at load1,load2 & $100 \mathrm{~W}, 200 \mathrm{~W}$ \\
\hline Duty ratio & 0.369 \\
\hline $\mathrm{R}_{1}, \mathrm{R}_{2}$ & $57.76 \Omega, 420.5 \Omega$ \\
\hline $\mathrm{L}_{1}, \mathrm{~L}_{2}$ & $4.8 \mathrm{mH}, 36.6 \mathrm{mH}$ \\
\hline $\mathrm{C}_{1}, \mathrm{C}_{2}$ & $48.5 \mu \mathrm{F}, 25.6 \mu \mathrm{F}$ \\
\hline
\end{tabular}

\section{Mppt technique}

Copyright $($ C) Authors 
As the PV module possess Non-linear characteristics, so the maximum power can be extracted only under specific conditions. Therefore, maximum power point tracking (MPPT) algorithms Such as incremental conductance (IC) method is used in PV array to maximize the output power. IC technique can track even with rapidly varying irradiance conditions with high accuracy.

\section{Results}

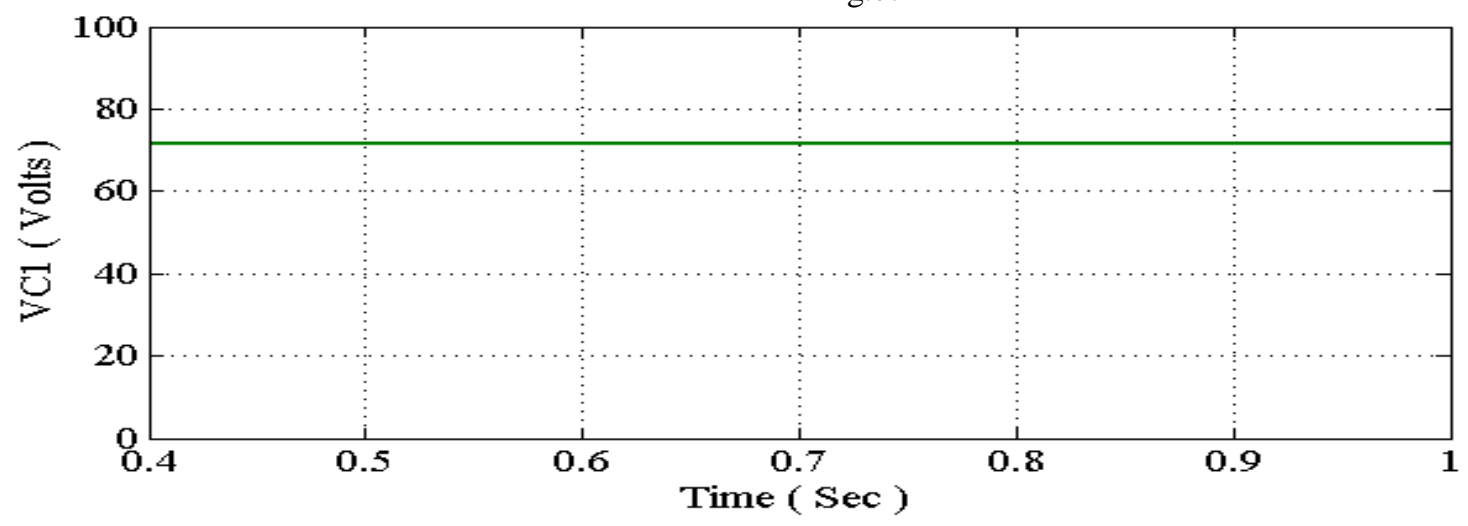

Fig. 4. Voltage across $\operatorname{Load}_{1}\left(\mathrm{~V}_{\mathrm{Cl}}\right)$

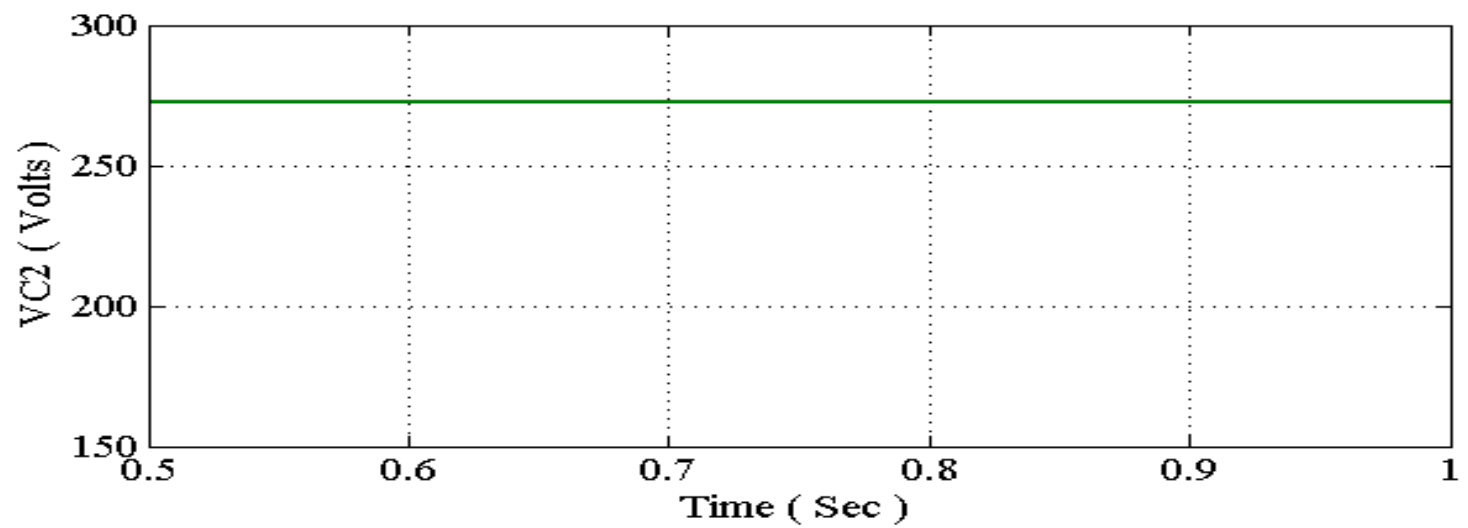

Fig. 5. Voltage across $\operatorname{Load}_{2}\left(\mathrm{~V}_{\mathrm{C} 2}\right)$

\section{(a) Simulation Results of PV Module With IC}

\section{Method}

The proposed converter is realized using MATLAB/Simulink by considering source as PV cell with IC method and results are shown in this secession. Voltage across load 1 and load 2 are shown in Fig. 4 and Fig.5 respectively. Switching pulses to control switches are shown in Fig. 6 and Fig.7. 


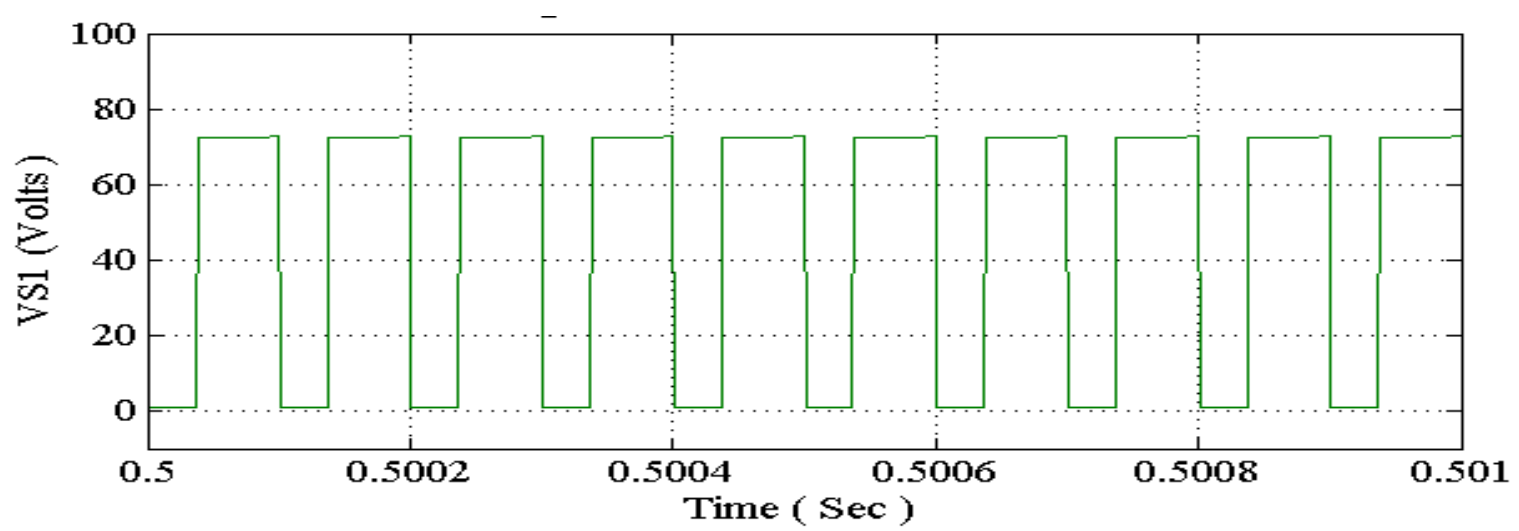

Fig. 6. Voltage stress across Switch $S_{1}\left(V_{S 1}\right)$

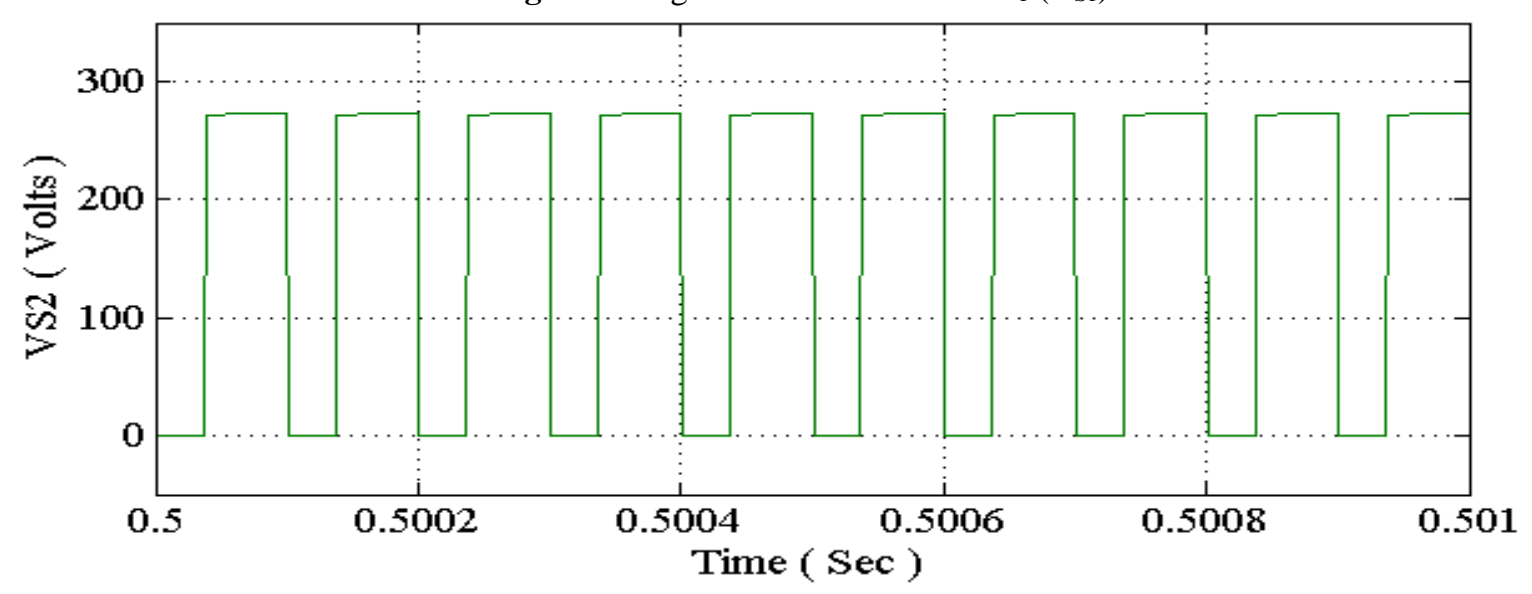

Fig. 7. Voltage stress across $S_{2}$ and similar to $S_{3}$

(b) Simulation Results of IC Method and Wind Energy:

The proposed converter is realized using MATLAB/Simulink by considering source as wind

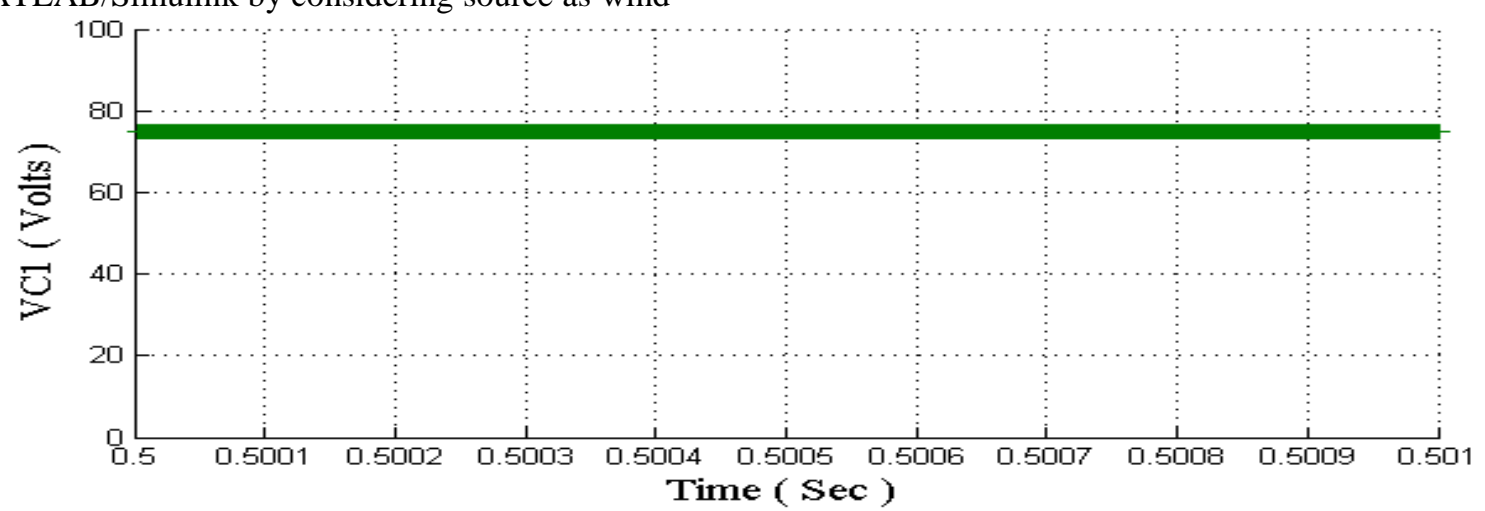

Fig. 8. Voltage across $\operatorname{Load}_{1}\left(\mathrm{~V}_{\mathrm{C} 1}\right)$ energy system with IC method and results are shown in this secession. Voltage across load1 and load2 are shown in Fig. 8 and Fig.9 respectively. Fig. 10 shows the source voltage and current. 


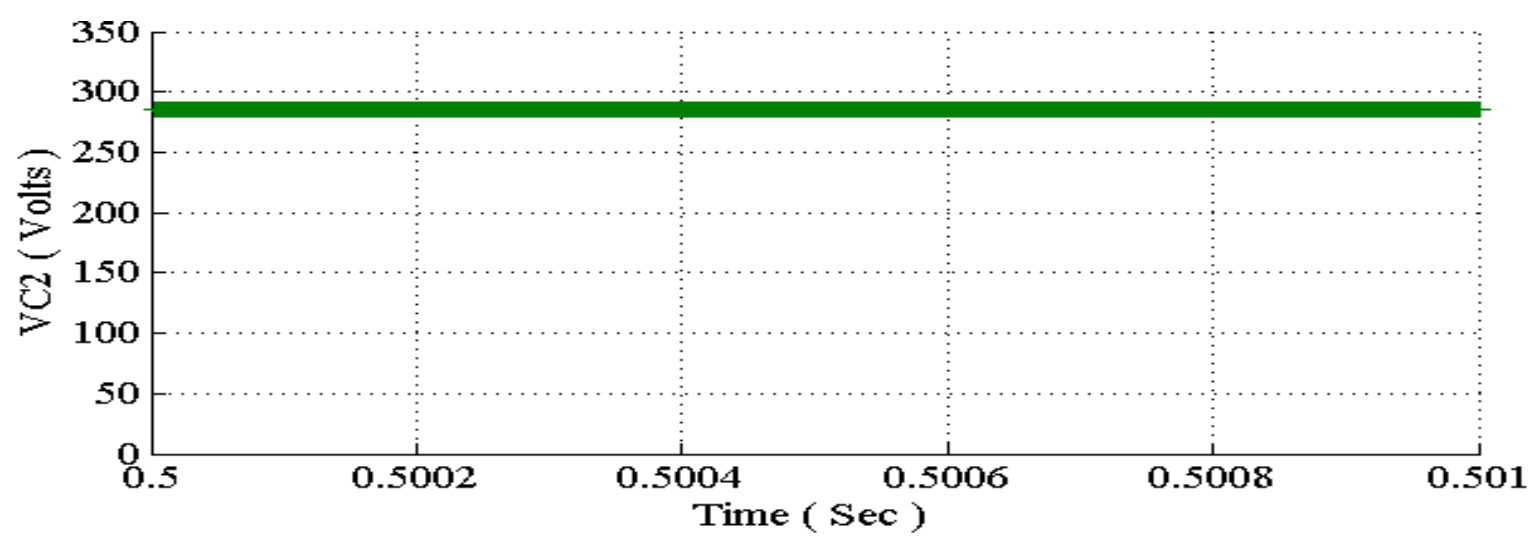

Fig. 9 .Voltage across $\operatorname{Load}_{2}\left(\mathrm{~V}_{\mathrm{C} 2}\right)$

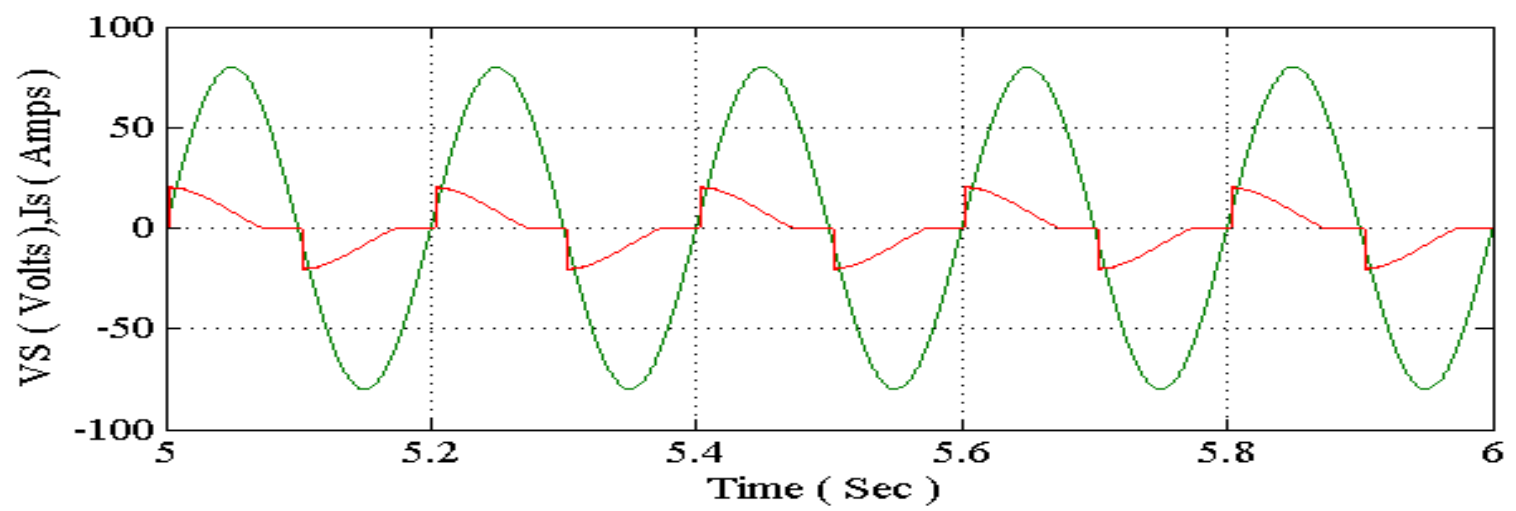

Fig.10. Input current and voltage waveform \& P.F $=0.9$

Table 2. Results comparison

\begin{tabular}{|c|c|c|c|c|c|c|c|c|c|c|c|c|c|}
\hline \multirow[t]{2}{*}{$\begin{array}{l}\text { Type of } \\
\text { converter }\end{array}$} & \multirow{2}{*}{$\begin{array}{l}T_{s} \\
(\operatorname{Sec} \\
)\end{array}$} & \multicolumn{4}{|c|}{$\begin{array}{l}\text { Ripple voltages }(V) \text { and } \\
\text { currents }(A)\end{array}$} & \multirow{2}{*}{$\begin{array}{l}\text { Voltag } \\
\text { e stress } \\
(V)\end{array}$} & \multirow[t]{2}{*}{$\eta(\%)$} & \multirow{2}{*}{$\begin{array}{l}\Delta \mathbf{I}_{\mathbf{L} 1} \\
(\boldsymbol{A})\end{array}$} & \multirow{2}{*}{$\begin{array}{l}V_{s I} \\
(V)\end{array}$} & \multirow{2}{*}{$\begin{array}{l}V_{S 2} \\
(V)\end{array}$} & \multirow{2}{*}{$\begin{array}{l}\Delta I_{L 2} \\
(A)\end{array}$} & \multirow[t]{2}{*}{$\begin{array}{c}M_{p} \\
(\%)\end{array}$} & \multirow[t]{2}{*}{$P F$} \\
\hline & & $\Delta V_{C I}$ & $\Delta I_{O I}$ & $\Delta V_{C 2}$ & $\Delta I_{O 2}$ & & & & & & & & \\
\hline $\begin{array}{l}\text { Converte } \\
\mathbf{r} \text { without } \\
\text { MPPT }\end{array}$ & 0.6 & 2 & $\begin{array}{l}0.03 \\
5\end{array}$ & 5 & 0.01 & 74 & $76 \%$ & 0.1 & 73 & 700 & 0.25 & 19.2 & - \\
\hline $\begin{array}{l}\text { Converte } \\
\text { r with } \\
\text { MPPT }\end{array}$ & 0.37 & 0.4 & $\begin{array}{l}0.00 \\
7\end{array}$ & 0.75 & $\begin{array}{l}0.001 \\
5\end{array}$ & 72 & $\begin{array}{l}70.8 \\
\%\end{array}$ & 0.1 & 72.5 & 273 & 0.1 & - & - \\
\hline $\begin{array}{l}\text { Solar and } \\
\text { wind as } \\
\text { input }\end{array}$ & 0.37 & 0.4 & 0.02 & 0.8 & $\begin{array}{l}0.001 \\
8\end{array}$ & 76 & $\begin{array}{l}67.5 \\
\%\end{array}$ & 0.4 & 73 & 288 & 0.1 & - & $\begin{array}{l}0.9 \\
\text { lag }\end{array}$ \\
\hline
\end{tabular}

low duty cycle, it also vanquishes the drawbacks of very severe duty ratios. For high-power

\section{Conclusion}

In this work, MATLAB/SIMULINK has successfully implemented the simulation of the high gain dc-dc converter with the IC MPPT algorithm. As it can reach a high voltage with a

Copyright $($ C) Authors applications and for low-power applications, two different dc bus voltages can be preserved, making more fitting for DC-Micro Grid applications. As a result, the developed system has many advantages over individual step up DC-DC Converter such as

ISSN (Print): 2204-0595

ISSN (Online): 2203-1731 
reduced switch stress, reduced settling time and the output voltage ripple and current ripple has decreased. Comparison of results is shown in Table 2.

\section{References}

[1] Siva kumar.K and manoranjan sahoo "High Gain step up DC-DC Converter for DC Micro Grid Applications," 978-1-4799-45986/14/\$31.00_c 2014 IEEE, colombo, 2014.

[2] Rou-yong duan,c y lin and chang, "High efficiency DC-DC converter with high voltage gain and reduced stress", IEEE Tranc.,on Ind. Elect. ,vol.54,2007

[3] Sudarsan, M.V., Babu, C.S. \& Satyanarayana, S. "High performance analysis of interleaved high-gain converter with active switched inductor using intelligent controller”, J.Supercomput (2021). https://doi.org/10.1007/s11227-020-03546-X

[4] Polamraju V S, M S Rao, N B Kumar, A S babu ,"design of fuzzy logic based photovoltaic fed battery charging system", J. Green Eng. Vol 9, 2019,p.p.270-281.

[5] M S Rao, Ch S Babu, Satyanarayana S, C B Naidu P , “ Digital fuzzy current mode controlled integrated pfc converter with external ramp compensation”, J Circu Sys Comp, vol 27, 2018, p.p1850147-1850223.

[6] D. Bao, A. Kumar, X. Pan, X. Xiong, A. R. Beig and S. K. Singh, "Switched Inductor Double Switch High Gain DC-DC Converter for Renewable Applications," in IEEE Access, vol. 9, 2021, pp. 14259-14270.

[7] D.N.S.Saranya, A.R.VijayBabu, G.Srinivasa Rao, Y.R.Tagore, N.Bharath Kumar, "Fuel Cell Powered Bidirectional DC-DC Converter for
Electric Vehicles", J. of Conl. theory and Appl., Vol.8, 2015 , Pp.109-120.

[8] Subbarao M, Ch. SaiBabu, S. Satyanarayana," Design and analysis of variable switching frequency controlled integrated switched mode power converter for class $\mathrm{C} \&$ class $\mathrm{D}$ appliances", Ain Shams EngJol.,vol. 9 (2018),p.p 2849-2858. 